\title{
高齢者PTCA の成績および長期予後についての検討
}

$\begin{array}{lllll}\text { 張 念 中* } & \text { 阿 部 博 幸** 水 見 和 久** } \\ \text { 竹 本 明子** } & \text { 鎌 田 力三郎** } & & \end{array}$

\section{I. 緒 言}

本邦においては平均寿命が年々延長し, 1987 年 の厚生省による人口統計では男性 75.23 歳, 女性 80.93 歳と世界一の長寿国となった ${ }^{11}$ 。一方, 高 齢者の占める人口構造比率は急速に増加し, 厚生 省人口問題研究所の「日本の将来推計人口」の報 告書によれば，現在日本の 65 歳以上の老年人口は $11.0 \%$ ，本世紀末には $16 \%$ に達すると予測され $る^{2}$. このように高齢化や欧米なみの食生活の変 化なぞで高齢者の虚血性心疾患はますます増加傾 向にある ${ }^{3,4)}$.

従来, 虚血性心疾患の治療法として, 内科的薬 物療法を除けば, 冠状動脈バイパス手術 (以下 CABG) は主流となっていた。1977年 Grüntzig が, バルーン・カテーテルにより冠状動脈狭窄部 㧒張に成功し, 虚血性心疾患を開胸せずに血行再 建をはかる方法として，注目されるようになっ た5). 最近, 経験の集積やバルーンを含めたシス テムの改良により，適応は大幅に拡大されてきた。 すなわち，適応条件には，(1)狭心症を有すること， (2)可逆的な心筋虚血が証明されること, (3)限局性 で血行力学的に有意の狭窄を有することの 3 点に 要約された ${ }^{6 \sim 8)}$.

今回, われわれは適応拡大の試みとして, 高齢 者患者 PTCA の有用性 ·安全性 - 予後について 検討してみた.

* 中華民国台湾台北医学院内科

** 日本大学医学部放射線科 原稿受取日：1987年 11 月 30 日

採用決定日：1988 年 4 月 11 日

\section{II. 対象および方法}

対象は連続施行した PTCA 74 例, 98 標的病変 について, 高齢者群 (65 歳以上, 65 82 歳, 平均 $70.1 \pm 5.2$ 歳), 14例，16標的病変および非高齢者 群 (65 歳未満, 32 64 歳, 平均 $51.5 \pm 8.7$ 歳), 60 例, 82 標的病変の 2 群にわけて, PTCA の初 期成績・合併症・再発・再 PTCA の成績・遠隔 期成績などについて比較した.

実際の手技は通常 8F のガイディング・カテー テルを大腿動脈より挿入し, Simpson-Robert の バルーン・カテーテルおよび各種ガイドワイヤー を適宜選択し, PTCA を施行した.

初期成功 (primary success) は次のとおりであっ た. 患者成功 (patient success) はPTCA 施行に より, 臨床症状の改善を認めたものとし, 標的成 功 (target success) は PTCA 施行により，20\%以 上の狭窄拡大を認めたものとした ${ }^{9)}$. 再狭窄 (restenosis) の定義は PTCA によって得られた拡 張の $50 \%$ が狭窄した場合 ${ }^{10)}$ ，または単純に $30 \%$ 以上の狭窄度が増した場合11) と規定した。

統計学的処理には, $\chi^{2}$ test を用い, 両群の比率 の有意差検定を行った，危険率は $0.001,0.005$, 0.05, 0.01 の 4 段階にわたって検討した.

\section{III. 成 績}

まず，高齢者 PTCA の代表的な 2 例を呈示す る.

【症例 1】M.T., 82 歳, 男性, 社長. 18 年前 (64歳頃)に自動車運転中胸痛自覚した. その後, 入浴中や階段昇降時に胸痛を認めていたが，亜硝 
動脤硬化 Vol. 16 No. 31988

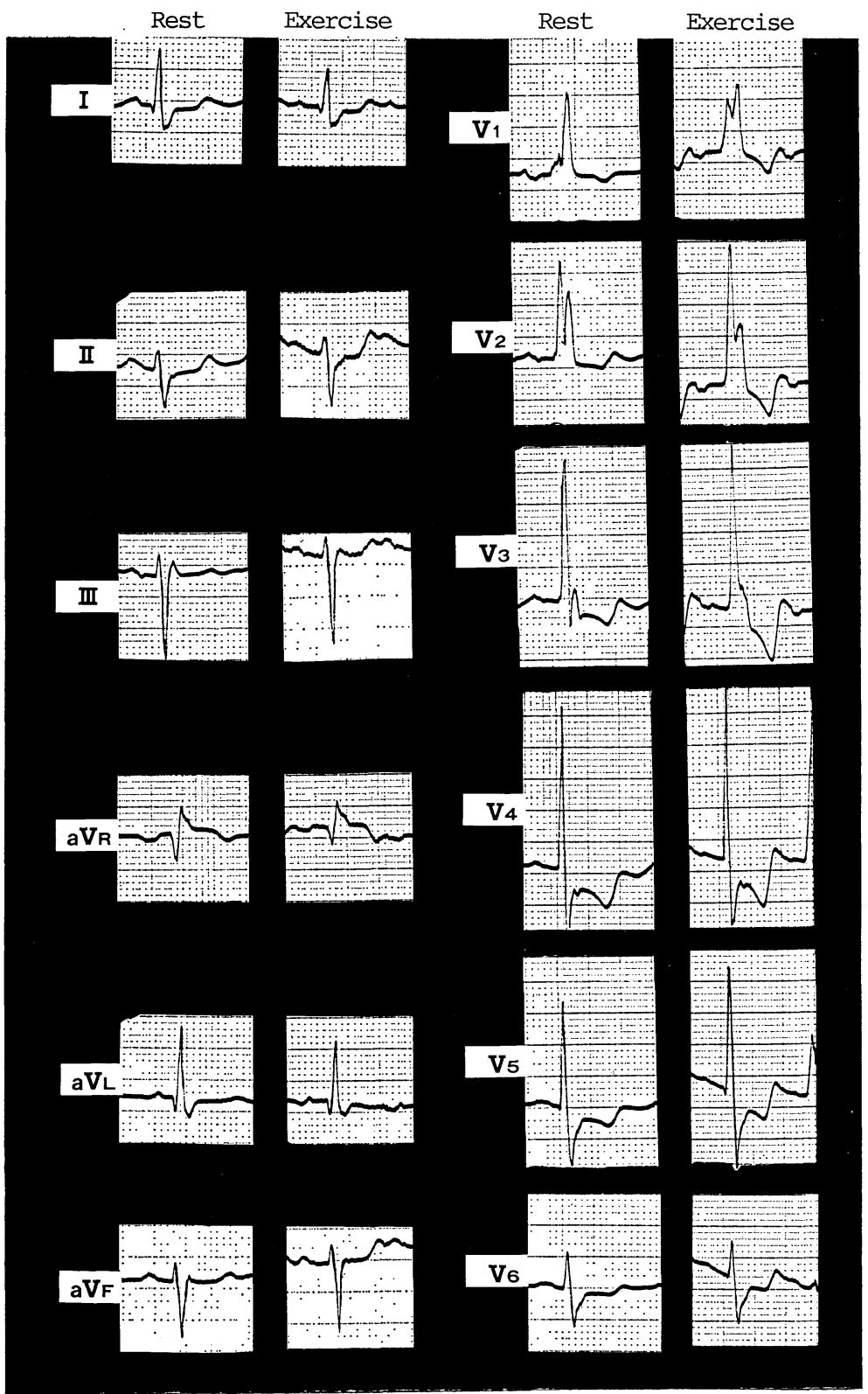

Fig. 1 (Case 1): 82 y/o, male, Master's two-step test (single).

酸剤舌下にて著効を呈していた。昭和 61 年 5 月頃 より発作が頻回となり，狭心症が不安定化したた めに入院となった. 入院後, 強力な内科治療を試 みたが，効果はみられなかった，冠状動脈危険因 子は高血圧, 高脂血症, 痛風であった. 検查成績 では BUN $34 \mathrm{mg} / \mathrm{d} l$, クレアチニン $3.3 \mathrm{mg} / \mathrm{d} l$, GFR $37 \mathrm{~m} l / \mathrm{min}$ で, 腎機能の軽度低下を認めた。
Master's two-step test にて, 前胸部誘導に広範囲 な虚血性変化を認めた (Fig. 1). 冠状動脈造影に て, 左主幹部末梢部 $(50 \%)$, 左前下行枝 $(75 \%)$ ならびに右冠状動脈近位部 $(90 \%)$ に，それぞれ高 度狭窄を認めた。また，右冠状動脈から左冠状動 脈へは良好な側副血行路を認め, 左冠状動脈の領 域を灌流し, viability が保たれていた (Fig. 2-a, b), 


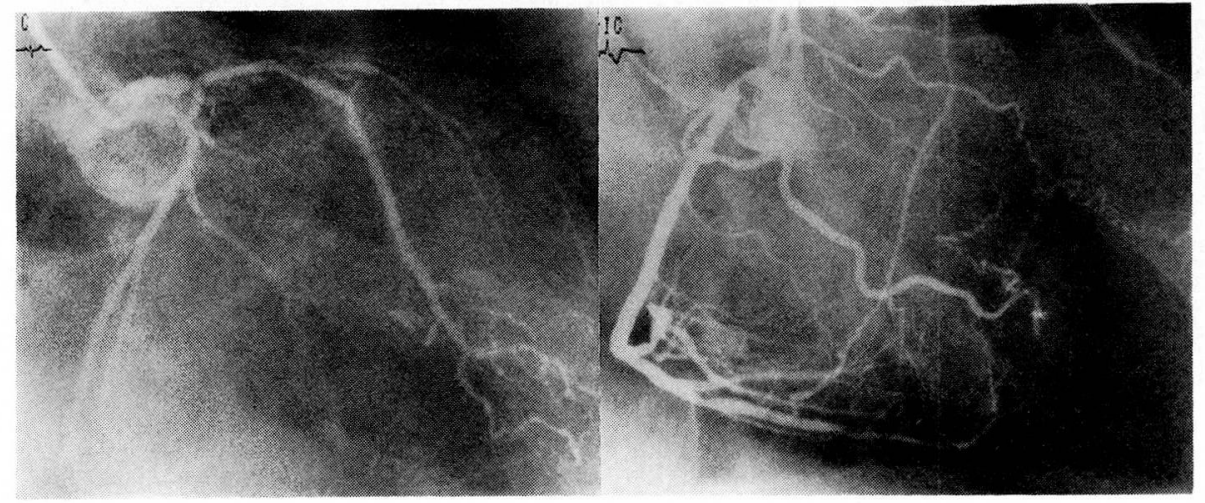

(a)

(b)

Fig. 2 (Case 1): Left coronary artery, RAO view, severe stenosis at bifurcation of main left coronary artery. A subtotal occlusion in the left anterior descending artery is shown (a); Right coronary artery, RAO view. A $90 \%$ stenosis is seen in the proximal segment of the right coronary artery. Jeopardized collaterals are shown (b).

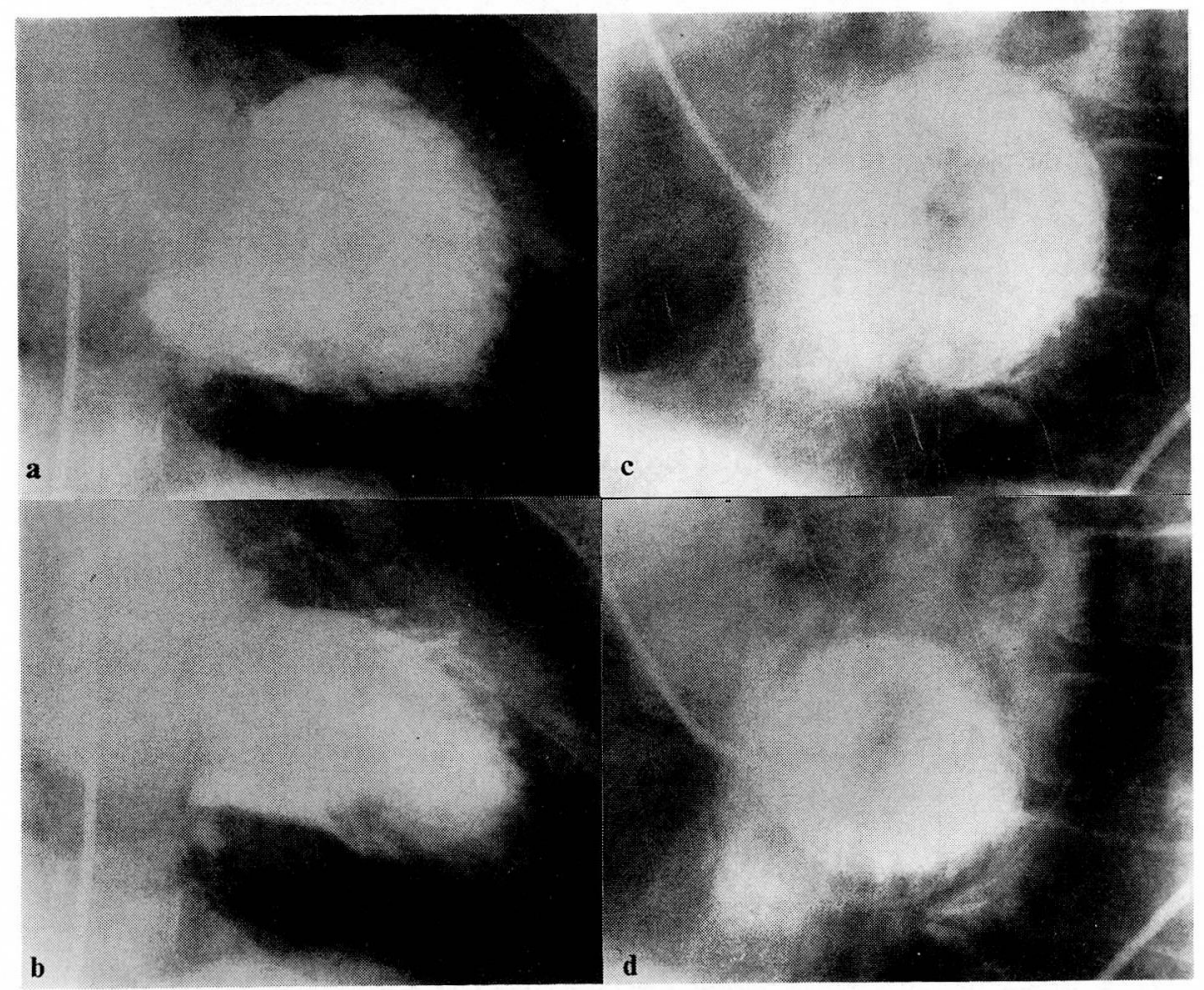

Fig. 3 (Case 1): Left ventriculogram. RAO view, end-diastole (a), RAO view, endsystole (b), LAO view, end-diastole (c), LAO view, end-systole (d). 


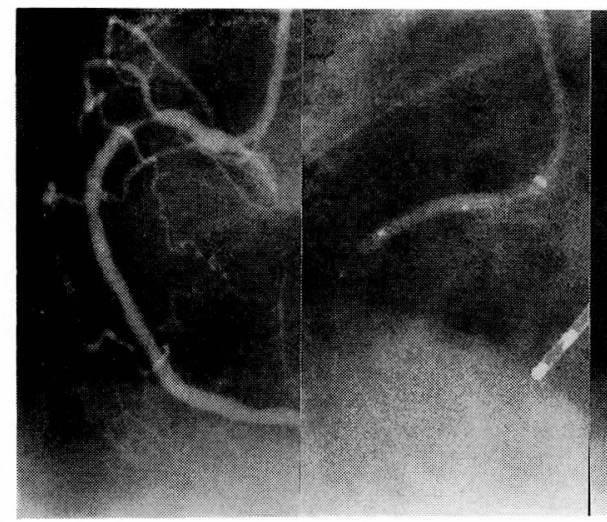

(a) (b)

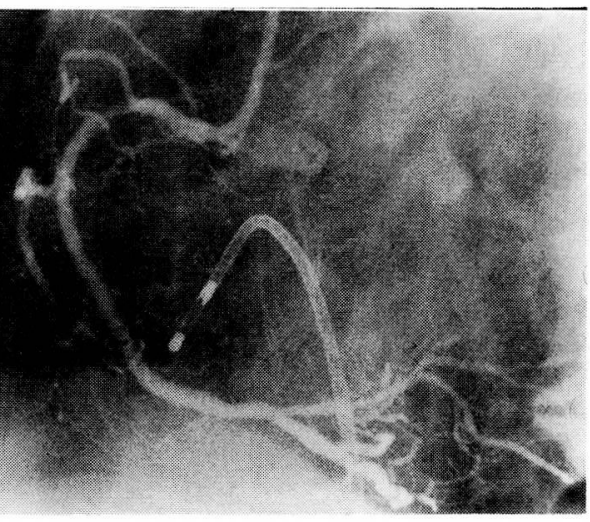

(c)

Fig. 4 (Case 1): Right coronary artery, LAO view, Pre-PTCA (a); A Simpson-Robert $3 \mathrm{~mm}$ dilatation balloon is in place (b); Right coronary artery, LAO view, PostPTCA (c).

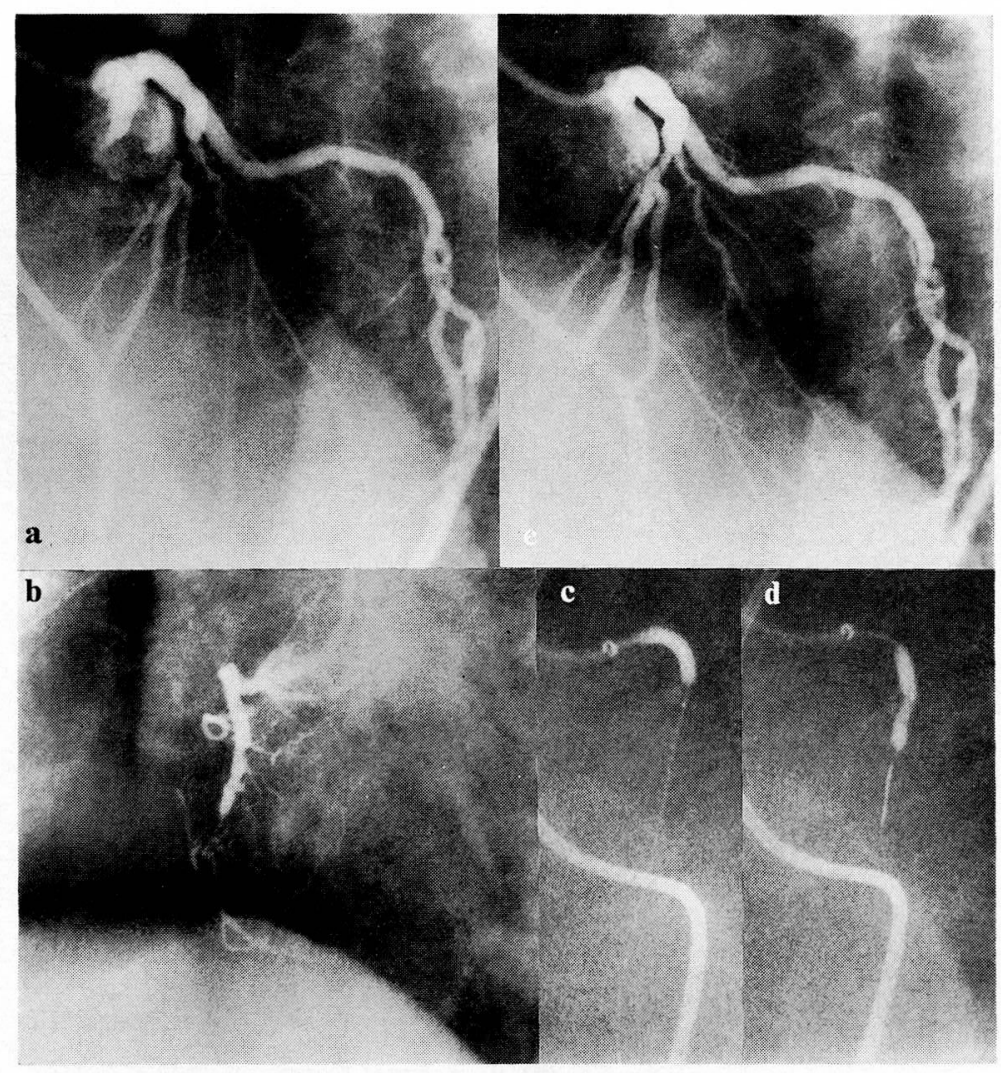

Fig. 5 (Case 2): Left coronary artery, LAO view, Pre-PTCA (a); Right coronary artery, LAO view (b); Simpson ultra-low profile $3 \mathrm{~mm}$ dilatation balloon (c); HartzlerLPS $3 \mathrm{~mm}$ dilatation balloon (d); Left coronary artery, LAO view, Post-PTCA (e). 
しかしながら，その右冠状動脈近位部は高度狭窄 像を呈しており，側副血行路が jeopardize 化され て抢り，狭心症の不安定化の主因と考えられた (Fig. 2-b). 左心室造影 (Fig. 3) では，心駆出率 $38 \%$ で，びまん性に左室壁運動の低下を認めた.

右冠状動脈近位部病変に対して, Simpson-Robert の $3 \mathrm{~mm}$ バルーン・カテーテルを挿入し, PTCA を施行した (Fig. 4-b). その狭窄度は $90 \%$ から $30 \%$ に改善された (Fig. 4-a, c). 術後，前胸部痛 が消失し良好な経過をみている，本症例は active な社会生活を行っており，最近狭心症が不安定化 し, 一応, CABG も考慮した. 右冠状動脈近位 部病変に対してのPTCA 施行には, 現在禁忌と されている. 左主幹部病変と同等であり, リスク は高いことは事実であったが，82歳の高齢者で腎 不全および心機能不全を併発しており，むしろ CABG の方がリスクが高いと考えられ，PTCA を選択し成功した症例である.

【症例 2】S.O., 73 歳, 男性. 20 年前に労作時 狭心症初発, 最近発作が頻回となり，内科治療に 抵抗であったために入院となった. 冠状動脈造影 所見では，左前下行枝近位部に subtotal な狭窄が あり (Fig. 5-a), 右冠状動脈は完全閉塞であった (Fig. 5-b). 左前下行枝狭窄に対して, Simpson ultra-low profile $3 \mathrm{~mm}$ バルーン・カテーテルを 挿入し，PTCAを試みたが (Fig. 5-c)，しかし， 病変部が硬く, バルーン・カテーテルが通過でき ず, Hartzler-LPS $3 \mathrm{~mm}$ バルーン・カテーテルを 入替えて成功した (Fig. 5-d, e). 本症例のように, 長期間にわたり, 狭心痛に悩まされた高齢者では, 病変部の硬さが予想される. 適時にバルーン・カ テーテルを変更し, 慎重な操作により, 成功率の 向上をはかるべきである.

以下われわれの成績を述べる.

\section{1. 臨床データおよび造影所見 (Table 1)}

高齢者群に冠状動脈 3 枝病変例 $(\mathrm{p}<0.05)$, 左 心室機能低下例 $(\mathrm{p}<0.005)$ が有意に多かった. ま た, 高齢者群に女性患者, 不安定狭心症例, カナ ダ心臟協会で狭心症重症度分類の 3 度以上の重症 例が多かった。病枝分布 $(75 \%$ 以上の内径狭窄を 有するもの) では, 高齢者群で右冠状動脈に有意 狭窄を有するものが多いが，有意差はなかった。
Table 1 Clinical and angiographic characteristics

\begin{tabular}{|c|c|c|}
\hline & $\begin{array}{c}\text { Elderly } \\
(\geqq 65 \text { years }) \\
70.1 \pm 5.2 \text { years } \\
(65-82 \text { years })\end{array}$ & $\begin{array}{c}\text { Younger } \\
(<65 \text { years }) \\
51.5 \pm 8.7 \text { years } \\
(32-64 \text { years })\end{array}$ \\
\hline No. of patients & 14 & 60 \\
\hline Male & $10(71 \%)$ & $55(92 \%)$ \\
\hline \multicolumn{3}{|l|}{ Coronary arteries } \\
\hline \multicolumn{3}{|l|}{ Narrowed $\geq 75 \%$} \\
\hline 1-Vessel & $6(43 \%)$ & $36(60 \%)$ \\
\hline 2-Vessel & $4(29 \%)$ & $19(32 \%)$ \\
\hline 3-Vessel* & $4(29 \%)$ & $5(8 \%)$ \\
\hline Target Artery & 16 & 82 \\
\hline LAD & $10(63 \%)$ & $58(71 \%)$ \\
\hline RCA & $5(31 \%)$ & $10(12 \%)$ \\
\hline LCX & $1(6 \%)$ & $11(13 \%)$ \\
\hline LMT & 0 & 1 \\
\hline Diagonal & 0 & 1 \\
\hline Bypass To LAD & 0 & 1 \\
\hline \multicolumn{3}{|c|}{ Anginal Class (Canadian Heart Association) } \\
\hline Class 0 & 0 & 1 \\
\hline Class 1 & 0 & 5 \\
\hline Class 2 & 3 & 11 \\
\hline Class 3 & 9 & 25 \\
\hline Class 4 & 2 & 18 \\
\hline Unstable angina & $11(79 \%)$ & $32(53 \%)$ \\
\hline \multicolumn{3}{|l|}{ Prior myocardial } \\
\hline Left ventricular** & $3(21 \%)$ & $1(2 \%)$ \\
\hline \multicolumn{3}{|c|}{ Ejection fraction $(<45 \%)$} \\
\hline Prior bypass surgery & 0 & 1 \\
\hline
\end{tabular}

\section{2. 初期成績 (Table 2)}

PTCA 患者成功率は高齢者群で，12/14 例 $(86 \%)$, 非高齢群で, $57 / 60$ 例 $(95 \%)$, 標的病変 成功率は高齢者群で, $14 / 16$ 病変 $(88 \%)$, 非高齢 者群で, 78/82 病変 $(95 \%)$, 高齢者群がやや低い が，有意差を認めず，両群ともに良好な成績であ った. 冠状動脈狭窄度は高齢者群で, 平均 $87 \pm 10 \%$ から $26 \pm 17 \%$ に, 非高齢者群で, 平均 $85 \pm 10 \%$ から $18 \pm 4 \%$ に改善された. 複数標的 の拡張 (multiple dilatation) は高齢者群で，2/14 例, 非高齢者群で, 14/60 例, 患者成功率は高齢 者群で，2/2 例 (100\%), 非高齢者群で，13/14 例 $(93 \%)$, 両群ともに良好な成績であった. 不安定 狭心症に対して, PTCA の患者成功率は高齢者群 で， 9/11 例 (82\%), 非高齢者群で， 28/32 例 $(88 \%)$, 全体的患者成功率に比べ，やや低い傾向 
動脈硬化 Vol.16 No. 31988

Table 2 Primary results of PTCA

\begin{tabular}{|c|c|c|}
\hline & $\begin{array}{l}\text { Elderly } \\
(\mathrm{N}=14)\end{array}$ & $\begin{array}{l}\text { Younger } \\
(\mathrm{N}=60)\end{array}$ \\
\hline Angioplasty attempts & 16 & 82 \\
\hline \multicolumn{3}{|l|}{$\begin{array}{l}\text { Number of attempts } \\
\text { per patient }\end{array}$} \\
\hline 1 lesion attempted & 12 cases $(86 \%)$ & 46 cases $(77 \%$ \\
\hline 2 lesions attempted & 2 cases & 9 cases $(15 \%$ \\
\hline 3 lesions attempted & 0 & 3 cases \\
\hline 4 lesions attempted & 0 & 1 case \\
\hline 5 lesions attempted & 0 & 1 case \\
\hline \multicolumn{3}{|l|}{$\begin{array}{l}\text { Mean percent diameter } \\
\text { stenosis }(\%)\end{array}$} \\
\hline Before PTCA & $87 \pm 10$ & $85 \pm 10$ \\
\hline After PTCA & $26 \pm 17$ & $18 \pm 4$ \\
\hline \multicolumn{3}{|l|}{ Success } \\
\hline \multicolumn{3}{|l|}{$\begin{array}{l}\text { Angiographic } \\
\text { success/total }\end{array}$} \\
\hline lesions & $14 / 16(88 \%)$ & $78 / 82(95 \%)$ \\
\hline \multicolumn{3}{|l|}{ Patients clinical } \\
\hline \multicolumn{3}{|l|}{ Clinical success in } \\
\hline multiple dilatation & $2 / 2(100 \%)$ & $13 / 14(93 \%)$ \\
\hline \multicolumn{3}{|c|}{$\begin{array}{l}\text { Reasons for unsuccessful dilatation } \\
\text { inability to cross the lesion }\end{array}$} \\
\hline of balloon catheter & 1 & 1 \\
\hline of guidewire & 0 & 3 \\
\hline $\begin{array}{l}\text { inability to dilate the } \\
\text { lesion }\end{array}$ & 1 & 0 \\
\hline
\end{tabular}

があったが，両群間の比較では成績の差はなかっ た. 不成功の理由は，バルーン通過不能では，高 齢者, 非高齢者群各 1 例, ガイドワイヤー通過不 能では, 非高齢者 3 例, 病変部拡張不能では, 高 齢者 1 例のみであった。

\section{3. 合 併 症 (Table 3)}

PTCA 施行による合併症の発生では, いずれの 群においても重篤な合併症は経験せず．非高齢者 群に後壁に小さな非貫壁性梗塞が 1 例のみであっ た.

\section{PTCA 後の経過および再発 (Table 4)}

初期成功後の経過追跡中, 臨床症状の再発を認 めた症例は，高齢者群で，3/12 例 $(25 \%)$, 非高齢 者群で，7/57 例 (12\%)，高齢者群に多い傾向があ ったが，有意差を認めなかった．臨床症状の再発 を認めた全例に対して，冠状動脈造影を行い，全 症例に再狭窄を認めた，高齢者群の全例，非高齢
Table 3 Complications encountered during initial PTCA

\begin{tabular}{lll}
\hline & $\begin{array}{l}\text { Elderly } \\
(\mathrm{N}=14)\end{array}$ & $\begin{array}{l}\text { Younger } \\
(\mathrm{N}=60)\end{array}$ \\
\hline Myocardial infarction & 0 & $1(1.7 \%)^{*}$ \\
Emergency bypass surgery & 0 & 0 \\
Mortality & 0 & 0 \\
Prolonged angina & $2(14.3 \%)$ & 0 \\
Coronary spasm & $1(7.1 \%)$ & $2(3.3 \%)$ \\
Coronary dissection & 0 & $4(6.7 \%)$ \\
Ventricular fibrillation & 0 & $1(1.7 \%)$ \\
\hline
\end{tabular}

Multiple complications often were encountered in the same patient

*Small, nontransmural posterior infarction

者群の $86 \%(6 / 7$ 例) で, 臨床症状の再発は初期 成功後 6 か月以内であった. 臨床症状の再発を認 めた高齢者 3 例に対し, 1 例は内科治療にて症状 のコントロールができたが，非高齢者 7 例に対し， 2 例が CABG で，その他の全症例に対して，再 PTCA を試みた. 再 PTCA の成功率は高齢者群 で, $2 / 2$ 例 $(100 \%)$, 非高齢者群で, $5 / 5$ 例 $(100 \%)$, 両群ともに再 PTCA の成功率は初期成功率より も高かった。 また, 再 PTCA 施行時, 両群とも に合併症の発生はなかった。一方, 術後経過追跡 中, 冠状動脈造影を再検査した症例は32例で, 無 症状の 22 例中 1 例のみが抎張された病変の再狭窄 を認めた。

\section{5. 遠隔期成績 (Table 5)}

初期成功後 1 年以上に追跡が可能であった症例 は高齢者群で， 9 例，非高齡者群で，45 例，平均 追跡期間は高齢 者群で，27.2 \pm 7.4 か月，非高齢 者群で，23.6土9.0 か月. カナダ心臟協会で重症 度の 1 度以上に改善を認めた症例は高齢者群で, $8 / 9$ 例 $(89 \%)$, 非高齢者群で, $43 / 45$ 例 $(96 \%)$, 両群ともに良好な経過であった。

\section{IV. 考察}

1979年に Grüntzig らの提唱した PTCA の適応 基準は，65 歳以上の高齢者は適応外とされてい た ${ }^{12)}$. しかしながら, 近年, 手技や器具の進歩に つれ，高齢者患者の PTCA が施行されるように なり, Stason ${ }^{13)}$ の統計によれば，高齢者 PTCA の実施は年々増え, 1984 年に施行した PTCA 件 数のうち，高齢者の占める割合は $26 \%$ であった。 
Table 4 Follow-up of initial PTCA patients

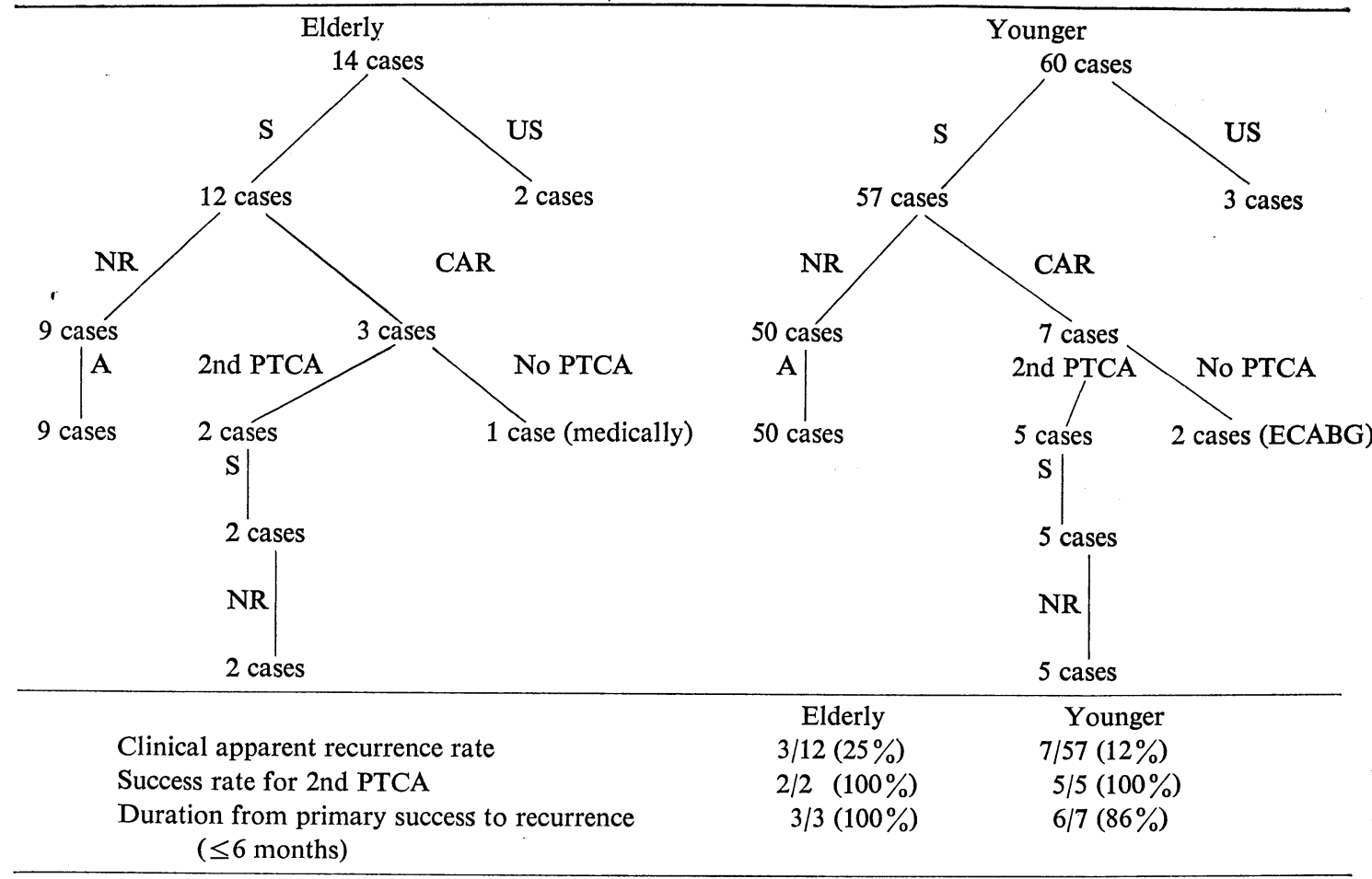

S: Successful; US: Unsuccessful; CAR: Clinical apparent recurrence; NR: No recurrence; ECABG: Elective coronary artery bypass graft surgery; A: Alive

Table 5 Patients follow-up ( $\geq 1$ year) after primary success

\begin{tabular}{lcc}
\hline & $\begin{array}{c}\text { Elderly } \\
(\mathrm{N}=9)\end{array}$ & $\begin{array}{c}\text { Younger } \\
(\mathrm{N}=45)\end{array}$ \\
\hline Angina & & 1 \\
Same & 1 & $43(96 \%)$ \\
Improved & 0 & 1 \\
Worse & 0 & $0 \%)$ \\
Anginal class (Canadian & Heart Association) \\
Class 0 & 8 & $29(64 \%)$ \\
Class 1 & 0 & 14 \\
Class 2 & 1 & 1 \\
Class 3 & 0 & 1 \\
Class 4 & 0 & 0 \\
Late myocardial infarction & 0 & 1 \\
Death & 0 & 0 \\
Bypass surgery during & & \\
follow-up period & 0 & 1 \\
\hline
\end{tabular}

PTCA はすでに CABG に匹敵する効果であると 評価され, PTCA にとって代わろうとしている14). 事実, 高龄者患者の冠状動脈硬化は高度であり,
さらに多臓器障害などの合併症を認めていること が多く, CABG 開胸術および術後管理の際はリ スクが高いと思われる15,16). これに反して, PTCA は侵襲性が少なく，入院期間も短いため, CABG に比べむしろ適した治療法とも考え られる17,18). Coronary Artery Surgery Study (CASS) の報告によれば，65歳以上の高齢者 CABG に伴った院内死亡率 (perioperative mortality) は 5.2\%19)であり，それに対して， National Heart, Blood and Lung Institute (以下 NHBLI) Registry の集計によると，65歳以上の高齢者 PTCA の院内死亡率は $2.2 \%$ 吕) であり，両者の血 行再建術を比較すると, PTCA の死亡率は CABG のそれよりも低いことになり，安全性が高いとい える.

しかし，高龄者の冠状動脈には高度狭窄，多枝 病変が多く，さらには解剖学的にも冠状動脈・末 梢動脈に蛇行が強いため, PTCA施行時の困難お 
よび危険性が予想される．NHBLI の報告によれ ば，高齢者群 PTCA の臨床成功率は $53 \%$ であり, 非高齢者群の $62 \%$ にくらべ有意な低下を示してい た.この理由として, 高龄者群にバルーン・カテ ーテルが狭窄部を通過しないことが主因であっ $た^{20)}$. さらには, 高齢者群の院内死亡率 $(2.2 \%)$ および待機的 CABG 施行率 $(25.4 \%)$ は，非高龄 者群の $0.7 \%$ および $8.1 \%$ にくらべ有意に高い. 高齢者群に女性例 - 重症狭心症例 - 冠状動脈多枝 病変・左主幹部病変例が多いことなどが理由とさ れていた ${ }^{20)}$.しかし, 最近では経験の集積や拡張 用バルーン・カテーテルを含めたシステムの改良 により著しく改善されてきている. Dorros ら 21) が 1985 年 5 月までに集計した 70 歳以上高齢者 109 例, 148 標的病変の PTCA 成績では, 患者成功率 $83 \%$, 標的病変成功率 $89 \%$, 死亡・緊急 $\mathrm{CABG}$ ・ 心筋梗塞などを含めた重大な合併症率は $5.5 \%$, 死亡率は $1.8 \%$ であり，優れた成績を報告してい る.また, Holt ら 22) の最近の報告によれば，70 歳以上の不安定狭心症 60 例に対しての PTCA 成 績では，患者成功率 $80 \%$, 死亡 0 の良好な成績が 得られている. 入院期間の短縮, 低費用さらには 早期社会復帰などの点からみても, PTCA が CABG よりも利点が多いと報告している ${ }^{23,24)}$. ただし，高齢者患者に対して，いったん PTCA が 不成功となり, 緊急 $\mathrm{CABG}$ になった場合, $\mathrm{CABG}$ の死亡率が一層高まることは銘記すべきである ${ }^{25)}$. 高齢者患者 PTCA 後の再狭窄の頻度が高く問 題視されている. Leimgruber ら ${ }^{26)}$ の報告によれ ば，加齢と再狭窄との関連性はなく，開大程度・ 不安定狭心症例 - 女性例, さらに狭心症歴の期間 が関連因子であると指摘している. 高齢者患者に 再狭窄が多いのは, 不安定狭心症例, 女性例, 長 期狭心症例が多いことによるものと考えられる.

適宜バルーン・サイズを大きいものに選択し, 十 分な拡張が得られれば再狭窄率を減少しえると報 告されてはいるが27)，再狭窄の機序が未だ完全に 解明されていない現時点では, 再狭窄の予防は確 かなものがないといっても過言ではない7).

高齢者患者再狭窄例の再 PTCA の成績および 初期成功後の遠隔期成績についての報告は未だ少 ない28,29). Dorros ら ${ }^{21)}$ の報告によれば，高齢者
患者における臨床症状再発例の再 PTCA の成功 率は初期成功率よりも高いと述べている. 一方, Dorros ら ${ }^{21)}$ および Raizner ら ${ }^{30)}$ の報告によると， 高齢者患者 PTCA 施行後, 平均 2 年間の追跡で は，約 $90 \%$ の患者が臨床症状の改善を認めている. 今後, 再狭窄の問題も含めて, さらに長期間の観 察により, 再検討の必要があると思われる.

\section{V. 結 論}

PTCA 74 例, 98 標的病変について, 高齢者群 (65 歳以上) および非高齢者群 (65 歳末満) の 2 群 にわけて比較検討した。

1）患者成功率は, 高齢者群 $86 \%$, 非高齢者群 $95 \%$, 標的病変成功率は高齢者群 $88 \%$, 非高齢者 群 $95 \%$ で, 両群間に有意差を認めず，良好な成績 であった. 複数標的の患者成功率は高齢者群 $100 \%$, 非高齢者群 $93 \%$ であった，不安定狭心症 に対して, PTCA の患者成功率は高龄者群 $82 \%$, 非高齢者群 $88 \%$ であった。

2）両群ともに重大な合併症を認めなかった.

3）臨床症状の再発は高齢者群 $25 \%$, 非高齢者 群 $12 \%$ で，高㱓者群にやや多い傾向がみられたが， 有意差を認めなかった。

4) 再 PTCA の成功率は両群ともに $100 \%$ であ った.

5) 両群の遠隔期成績 (1 年以上の 追跡) : 高齢 者群 (平均追跡期間 : $27.2 \pm 7.4$ か月) $89 \%$, 非高 齢者群 (平均追跡期間 : $23.6 \pm 9.0$ か月) $96 \%$ で, 症状の悪化を認めず，良好な経過である.

高龄者 PTCA の初期成功率は非高齢者と同様 に高く，良好な成績であった，再狭窄はやや多い 傾向にあるが，再 PTCA の成功率は高い。また， 遠隔期の成績は良好であり, 高齢者患者に対して, 試みるべき有用かつ安全な治療手段であると考え られた。

\section{文献}

1）財団法人厚生統計協会 : 国民衛生の動向・厚生の指 標, 臨時堌刊, 第 34 巻, 第 9 号, 通巻第 528 号, 東 京, p. 78, 昭和62年.

2) 同 1, p. 42.

3) 廣田安夫：老年者の虚血性心疾患—わが国の疫 学——. Geriatric Medicine, 17: 511-516 (1979). 
4) 籏野脩一: 老人の虚血性心疾患の国際比較. Geriatric Medicine, 17: 519-526 (1979).

5) Grüntzig, A. R.: Transluminal dilatation of coronary-artery stenosis. Lancet, 1: 263 (1978).

6) Anderson, H. V., Roubin, G. S., Leimgruber, P. P., Douglas, J. S., King III, S. B. and Grüntzig, A. R.: Primary success rates of percutaneous transluminal coronary angioplasty. Am. J. Cardiol., 56: 712717 (1985).

7) 阿部博幸, 水見和久, 吉田克哉, 竹本明子, 郭 仁 村, 馬渡耕史 : PTCAの適応挔大と問題点. 臨床放 射線, 31: 27-33(1986).

8) 阿部博幸 : 冠状動脈の PTA (PTCA) と冠状動脈血 栓溶解術 (PTCR). 日獨医報, 30: 198-206 (1985).

9) Detre, K. M., Myler, R. K., Kelsey, S. E., Van Raden, M. and Mitchell, H.: Baseline characteristics of patients in the National Heart, Lung, and Blood Institute percutaneous transluminal angioplasty registry. Am. J. Cardiol., 53: 7c-11c (1984).

10) Ichinger, T., Grüntzig, A. R., Hollman, J., King III, S. B., Douglas, J., Meier, B., Bradford, J. and Tankersley, R.: Should coronary arteries with less than $60 \%$ diameter stenosis be treated by angioplasty? Circulation., 68: 148-154 (1983).

11) Dangoisse, V., Guiteras Val, P., David, P. R., Lespérance, J., Crèpeau, J. Dyrda, I. and Bourassa, M. G.: Recurrence of stenosis after successful percutaneous coronary angioplasty (PTCA) . Circulation, 66 (Suppl. II): II-331 (1982).

12) Grüntzig, A. R., Senning, A. and Siegenthaler, W. E.: Nonoperative dilatation of coronary artery stenosis: percutaneous transluminal coronary angioplasty. N. Engl. J. Med., 301: 61-68 (1979).

13) Stason, W. B., Sanders, C. A. and Smith, H. C.: Cardiovascular care of the elderly: Economic considerations. JACC, 10 (Suppl. A): 18A-21A (1987).

14) Foster, E. D., Fisher, L. D., Kaiser, G. C., Myers, W. O., Carpenter, J., Abele, S., Ells, R. with the Principal Investigators of CASS and Their Associates: Potential for percutaneous transluminal coronary angioplasty before initial and repeat coronary artery bypass grafting in the coronary artery surgery study (CASS) registry population. Am. J. Cardiol., 53: 112c-115c (1984).

15) Loop, F. D.: Progress in surgical treatment of coronary atherosclerosis. Part 1. Chest., 84: 611624 (1983). Part 2. Chest., 84: 740-755 (1983).

16) Lytle, B. W. and Loop, F. D.: Elective coronary surgery. Cardiovasc. Clin., 12: 31-47 (1982).

17) Jang, G. C., Block, P. C., Cowley, M. J., Grüntzig, A. R., Dorros, G., Holmes, D. R., Kent, K. M., Leatherman, L. L., Myler, R. K., Sjolander, S. M. E., Stertzer, S. H., Vetrovec, G. W., Willis, W. H. and Williams, D. O.: Relative cost of coronary angioplasty and bypass surgery in a one- vessel disease model. Am. J. Cardiol., 53: 52c-55c (1984).

18) Zaidi, A. R., Hollman, J., Franco, I., Simpfendorfer, C. and Galan, K.: Coronary angioplasty: can you refer older patients? Geriatrics, 40: 38-44 (1985).

19) Gersh, B. J., Kronmal, R. A., Frye, R. L., Schaff, H. V., Ryan, T. J., Gosselin, A. J., Kaiser, G. C., Killip III, T., and Participants in the Coronary Artery Surgery Study: Coronary arteriography and coronary artery bypass surgery: Morbidity and mortality in patients ages 65 years or older, A report from the Coronary Artery Surgery Study. Circulation, 67: 483-491 (1983).

20) Mock, M. B., Holmes, D. R., Vlietstra, R. E., Gersh, B. J., Detre, K. M., Kelsey, S. F., Orszulak, T. A., Schaff, H. V., Piehler, J. M., Van Raden, M. J., Passamani, E. R., Kent, K. M. and Grüntzig, A. R.: Participants in the National Heart, Lung, and Blood Institute percutaneous transluminal coronary angioplasty registry: Percutaneous Transluminal Coronary Angioplasty (PTCA) in the elderly patients: Experience in the National Heart, Lung, and Blood Institute PTCA Registry. Am. J. Cardiol., 53: 89c-91c (1984).

21) Dorros, G. and Janke, L.: Percutaneous transluminal coronary angioplasty in patients over the age of 70 years. Cathet. Cardiovasc. Diagn., 8: 233-242 (1986).

22) Holt, G. W., Sugrue, D. D., Bresnahan, J. F. Vlietstra, R. E., Reeder, G. S., Bresnahan, D. R. and Holmes, D. R.: The results of percutaneous transluminal coronary angioplasty for unstable angina in the elderly. JACC, 9 (Suppl. A): 150A (1987).

23) Pepine, C., Roberts, A., Knauf, D. and Alexander, J.: Mortality, morbidity, and cost-effectiveness of coronary artery grafts surgery in the elderly. Eur. Heart J., 5: 306-317 (1984).

24) Kelly, M. E., Taylor, G. J., Moses, H. W., Mikell, F. L., Dove, J. T., Batchelder, J. E., Wellons, H. A. and Schneider, J. A.: Comparative cost of myocardial revascularization: percutaneous transluminal angioplasty and coronary artery bypass surgery. JACC, 5: 16-20 (1985).

25) Taylor, G. J., Rabinovich, E., Mikell, F. L., Moses, H. W., Dove, J. T., Batchelder, J. E., Wellons, H. A. and Schneider, J. A.: Percutaneous transluminal coronary angioplasty as palliation for patients considered poor surgical candidates. Am. Heart J., 111: 840-844 (1986).

26) Leimgruber, P. P., Roubin, G. S., Hollman, J., Cotsonis, G. A., Meier, B., Douglas, J. S., King III, S. B. and Grüntzig, A. R.: Restenosis after successful coronary angioplasty in patients with singlevessel disease. Circulation, 73: 710-717 (1986).

27) Schmitz, J. H., Esseu, R., Meyer, J. and Effert, S.: 
The role of balloon size for acute and late angiographic results in coronary angioplasty. Circulation, 70 (Suppl. II): II-295 (1984).

28) Meyer, J., Schmitz, J. H., Kiesslich, T., Erbel, R., Krebs, W., Dipl.-Ing., Schulz, W., Bordos, P., Minale, C., Messmer, B. J. and Effert, S.: Percutaneous transluminal coronary angioplasty in patients with stable and unstable angina pectoris; analysis of early and late results. Am. Heart J., 106: 973-980 (1983).
29) Meier, B., Grüntzig, A. R., Siegenthaler, W. E. and Schlumpf, M.: Long-term exercise performance after percutaneous transluminal coronary angioplasty and coronary artery bypass grafting. Circulation, 68: 796-802 (1983).

30) Raizner, A. E., Hust, R. G., Lewis, J. M., Winters, W. L., Batty, J. W. and Roberts, R.: Transluminal coronary angioplasty in the elderly. Am. J. Cardiol., 57: 29-32 (1986).

\title{
Summary
}

\section{The Primary Results and Long-term Outcome of Percutaneous Transluminal Coronary Angioplasty (PTCA) in the Elderly}

\author{
Nen-Chung Chang*, Hiroyuki AbE**, Kazuhisa Himi**, \\ Akiko TAKEMOTO** and Rikisaburo KaMATA** \\ *Department of Internal Medicine, Taipei Medical College, Taipei, Taiwan, Republic of China \\ **Department of Radiology, Nihon University, School of Medicine, Tokyo, Japan
}

Since PTCA required less stress and shorter hospitalization; therefore, expansion of its application for elderly patients with coronary artery disease is being attempted. In this paper, we explicated the primary results and long-term outcome of PTCA in the elderly.

On 74 PTCAs, 14 patients were 65 years or older (mean $70.1 \pm 5.2$ years). On angiography, elderly patients differed in the more frequent occurrence of three-vessel diease $(29 \%$ vs. $8 \%$ in younger patients, $\mathrm{p}<0.05)$ and left ventricular dysfunction $(21 \%$ vs. $2 \%$ in younger patients, $\mathrm{p}<0.005$ ).

Clinical primary success was achieved in $86 \%$ (12/14 cases), vs. $95 \%$ (57/60 cases) in younger patients. Angiographic primary success was achieved in $88 \%(14 / 16$ lesions) vs. $95 \%$ (78/82 lesions) in younger patients. Clinical success for unstable angina was achieved in $82 \%$, vs. $88 \%$ in younger patients; for multiple dilatation, $100 \%$ vs. $93 \%$ in younger patients. There was no major complication in both groups. Repeat angioplasty success for restenosis was achieved in all cases of both groups. Clinical follow-up more than one year in whom PTCA was successful showed that symptomatic improvement was achieved in $89 \%$, vs. $96 \%$ in younger patients. These data support the safety and clinical effectiveness of PTCA in elderly patients with coronary artery disease.

Key words: PTCA, elderly patients, coronary artery disease, primary success, long-term outcome. 